\title{
A Subjective Poverty Approach as an Alternative Measurement in Identifying the Poor and Needy
}

\author{
Azhana Othman, Abd Halim Mohd Noor and Mohamed Saladin Abdul Rasool \\ Centre for Islamic Philanthropy and Social Finance (CIPSF)
}

\begin{abstract}
Poverty can be measured directly (based on consumption) or indirectly (based on income). Both direct and indirect poverty measurement are called objective poverty measurement. Nonetheless, these indicators are not enough capture the multiple aspects of poverty. Therefore, the alternative measure of poverty is needed. Subjective poverty is an individual assessment of their own poverty status. The poor have their own understanding and interpretation of their socio-economic situation. Poverty could be analyzed in a more comprehensive and better dimension by combining objective and subjective measures in identifying the poor. The Millennium Development Goals Report (MDGR, 2015) designates that Malaysia has been successful eliminated objective poverty. Despite that, the issue of poverty still surfing especially the zakat authorities are experiencing increasing in the zakat applications categorized poor and needy each day. To avoid the situation where individuals are wrongly defined as poor or non-poor are to compile objective and subjective measures on poverty. The objectives of the study are to determine the criteria of subjective poor and to propose subjective poverty index (SPI) as an alternative poverty measurement. The empirical analysis was based of 507 zakat applicants of poor and needy in Melaka. The data was analysed using qualitative and quantitative methods in four phases of analysis. The findings confirmed that subjective poverty index (SPI) is an initial effort to explain poverty in the perspective of the poor.
\end{abstract}

Keywords: Objective Poverty, Subjective Poverty, Poor and Needy, Subjective Poverty Index (SPI), Zakat

\section{INTRODUCTION}

Niemietz (2011) defined subjective poverty as follow: 1) Relative poverty: its indicators are based on a country's income distribution. A household is poor if their income is far below those typical income of particular time and place; 2) Absolute poverty: its indicators are based on poverty lines; includes of a fixed level purchasing power or command over material resources; 3) Subjective poverty where each individual assesses their poverty status themselves. Veenhoven (2001) specified that the objective approach is focusing on measuring 'hard' facts, such as income in dollars or living accommodation in square meters. Meanwhile, the subjective approach in contrast considers as 'soft' matters includes satisfaction with income and perceived adequacy of dwelling.

The current monetary approach is questioned to be incapable to reflect the multidimensional nature of poverty. As a result, policy makers and researchers in developed country decide on using other approaches such as capability and social exclusion approaches which are multidimensional in nature that includes non-monetary indicators as mentioned by researchers such as Sen (1977, 1987, 1992); Nasbaum (1997, 2003); Laderchi (2000, 2003); Waggle (2005, 2007,2008); 
Alkire (2002, 2007, 2010); Ravallion $(1998,2012)$ and Nolan \& Whelan $(2010$, 2012). Alternative approach was advocated by Goedhart et.al (1977), Van Praag et.al (1980, 1982), Pradhan \& Ravallion (2000). Ravallion \& Lokshin (2002) indicated that poverty was a feeling and related to psychological issues.

It is also argued that absolute poverty may disappear as countries become richer but the relative deprivation and subjective poverty may persist. Applying different notions/metrics of poverty might produce different analytical results that, in turn, call for a different set of policy interventions. Thus, while most developing countries are still concerned with absolute poverty, many developed countries, particularly Organization for Economic Cooperation and Development (OECD) countries have already shifted their focus to relative and subjective poverty (OECD, 2011).

Therefore, the alternative measure of poverty is needed. One such alternative is the use of surveys that interrogate people about poverty. The poor will answer what is "the smallest amount of money a family needs each week to get along in this community", "what is the level of income below which families are unable to make ends meet" etc. That would remove some of the arbitrariness of the cut off line between poor and non-poor and putting that decision in the hands of the people themselves rather than the communities.

The needs of Subjective Poverty (SPI) measurement

The need for subjective indicators must also be judged against the limitations of objective indicators. Objective indicators provide only a part of the required information and give generally a better view on details rather than on the whole picture. Veenhoven (2001) agreed that social policy makers need both objective and subjective indicators as it combined the strengths of these indicators and avoid the discrepancies they show. For some purpose objective indicators are best suited, for other uses, subjective indicators are preferable. Assessments of overall life satisfaction are particularly needed to assess comprehensively policy success and to distinguish needs from wants. Most studies that analyze subjective poverty do not propose that subjective measures replace money-metric poverty measures. Rather, much of the research has investigated how to combine subjective and money-metric indicators to provide a more composite measure of poverty.

\section{METHODOLOGY}

This study encompasses two main research objectives. It also involved four analysis phases. The first objective was to identify dimensions of subjective poverty. It involves the phase 1, Participatory Poverty Assessment (PPA) and phase 2, survey. In the context of this study, the researcher conducted face-to-face interviews to validate the dimensions of poverty from the poor (respondents) perspective and to identify variables pertaining to each of the dimensions. For the second objective was to develop the Subjective Poverty Index (SPI). The third phase involves logistic regression analysis to examine the criteria for the proposed Subjective Poverty Index (SPI). Next, the fourth phase, that is formulating Subjective Poverty Index (SPI). It also involved the determination of the cut-off point or the threshold which is essential in defining poor. For this study, five different cut-of points were chosen to show how these different cut-offs would have impact on the overall identification of the poor group by the SPI. Lastly, the weightage of the dimensions of the SPI was determined. 
Phase 1: Participatory Poverty Assessment (PPA)

PPA is defined as an instrument for including poor people's views in the analysis of poverty and the formulation of strategies to reduce it through public policy (World Bank,2003). The rationale for Participatory Poverty Assessments (PPAs) is that for these policies to work, the voices of poor and marginalized people and their understandings of poverty need to be included. Failure to respect and respond to how poor people experience poverty and what they see as causing it can contribute to poverty reduction interventions missing their targets. Thus, in this study the beneficiary assessment approach was used.

The focus group is the zakat applicants will be asked to share their views on poverty especially on why they feel poor and the reason for applying zakat. Their views will list down the characteristics of the poor assess by themselves. They will divide into groups according to three districts. Then the common characteristics of the poor will be list down and rank. The first step is to list down the characteristics of the poor between intra group (different groups in the same district) and the second step is to list down the characteristics of the poor by comparing it between inter groups (between different groups in different districts).

\section{Phase 2: Survey}

Data for the study are gathered through a formal survey using a structured questionnaire. After the questionnaire was pre-tested and some of instruments were improved to ensure the available instruments are high internal consistency, the definite version of the questionnaires set is distributed to the selected respondents. The survey will be done by personal interview or face-to face interview. It was carried out in the way that the interviewer read the questions to the interviewee and wrote down his / her answers into the questionnaire offering additional explanations if necessary, to unsure clear and unambiguous responses to questions.

\section{Phase 3: To Examine the Criteria of Subjective Poverty Index}

The third phase involves analysing the characteristics of the subjective poverty and developing the relevant descriptive indicators. The analysis will be able to identify profile the criteria of the poor based on subjective poverty among zakat recipients. A subjective poverty measurement framework will be developed from the indicators. Focus group session will be held with practitioners and experts in the field to exchange ideas and feedback on the developed.

\section{Phase 4: Formulating Subjective Poverty Index}

The choice of dimensions and indicators to be included in the measurement of proposed Subjective Poverty Index is guided both by common empirical practice as well as particular data considerations for Malaysia. Hence, in formulating of Subjective Poverty Index, the steps are followed:

\section{Step 1 : Dimensions of Subjective} Poverty

From the preliminary study, the results showed that all respondents agreed that old age, lower education, jobless, no income, poor health status, no other income resource, no family support and financial stress are the factors that effect on why they feel poor. 
Step 2 : Weightage Determination for Subjective Poverty Index

After determining the indicators in the SPI, the weightage of each indicator was calculated to define the contribution of each indicators. The total weightage is 100. The indicators of SPI are assigned double equal weight. All dimensions are weighted equally and then all indicators within each dimension are weighted equally.

Step 3 : The Aggregate Deprivation CutOff

The subjective poverty score of each household is calculated with the help of a weighted sum of the number of deprivations, so that the subjective poverty score for each person lies between 0 and 100. The score increases as the number of deprivations of the person increases and reaches its maximum of 100 when the respondent is feeling poor in all component indicators. A person, who does not feel poor in any indicator, receives a score equal to 0 . Thus, the value of 0 indicate non-subjective poor at all on the selected indicators. While, the value of 100 indicate subjective poor based on the selected indicators. The next step is to determine the poverty cutoff for multidimensional measures are the share of weighted indicators in which a person or household must be deprived in order to be identified as subjective poor.

Step 4 : Formulation of Subjective Poverty Index

After determining the indicators to be included in the Subjective Poverty Index, the weighing of each indicator will be calculating to determine the contribution of each indicator. Equal weights across dimensions also ease the interpretation of the index for policy, to the extent that Atkinson et al (2002) recommend that dimensions be chosen such that their weights can be roughly equal. The total weightage of the indicators would be 100 . The formula for the subjective poverty index is as below:

$$
\mathrm{SPI}=\mathrm{W} 1 \mathrm{Z} 1+\mathrm{W} 2 \mathrm{Z} 2+\ldots \ldots .+\mathrm{WnZn} \times 100 \%
$$

Where $\mathrm{Z} 1, \mathrm{Z} 2 \ldots \mathrm{Zn}$ are determinants of subjective poverty and $\mathrm{W} 1, \mathrm{~W} 2 \ldots \mathrm{Wn}$ are the weightage.

Intensity of subjective poverty is negligible if household score is less than 20. Moderate subjective poor if household score is between 20 and 50. High subjective poor if household score is more than 50 but less than 75 . Very high subjective poor if the household score is more than 75 .

Example:

$\mathrm{SPI}=\mathrm{W} 1 \mathrm{Z} 1+\mathrm{W} 2 \mathrm{Z} 2+\mathrm{W} 3 \mathrm{Z} 3+\ldots \ldots . .=0$ (non-subjective poor)

$\mathrm{SPI}=\mathrm{W} 1 \mathrm{Z} 1+\mathrm{W} 2 \mathrm{Z} 2+\mathrm{W} 3 \mathrm{Z} 3+\ldots \ldots=100$ (subjective poor)

Finally, to utilized the proposed SPI in the multifaceted poverty measurement. Comparing the determinants of poverty across different poverty measures allows us a better understanding of the roles and robustness of various 
determinants of poverty. It also helps us to detect the key determinants that policy initiatives should focus on. It should also widen the perspective of Indonesian policy makers in proposing poverty alleviation policies.

For this study, five different cut-off points were chosen to show how these different cut-offs would have impact on the overall identification of the poor group by the SPI. After determining the indicators to be included in the Subjective Poverty Index, the third step was determining the weightage of the dimensions. The total weightage of the indicators would be 100 . The indicators of SPI are assigned equal weight. All dimensions are weighted equally and then all indicators within each dimension are weighted equally. Lastly, the fourth step was to formulate the SPI. The formula for the subjective poverty index is as below:

$$
\begin{gathered}
\mathrm{SPI}=(\mathrm{A} 1 * 4.77)+(\mathrm{A} 2 * 4.77)+(\mathrm{A} 3 * 4.77)+(\mathrm{B} 1 * 14.3)+(\mathrm{C} 1 * 7.15)+(\mathrm{C} 2 * 7.15)+(\mathrm{D} 1 * 14.3)+(\mathrm{E} 1 * 3 \\
58)+(\mathrm{E} 2 * 3.58)+(\mathrm{E} 3 * 3.58)+(\mathrm{E} 4 * 3.58)+(\mathrm{F} 1 * 14.3)+(\mathrm{G} 1 * 7.15)+(\mathrm{G} 2 * 7.15)
\end{gathered}
$$

\section{Where}

$\mathrm{A} 1=$ Able to work but inactive

A2 = Able to work but not able to get suitable work

A3 = Working but odd income

$\mathrm{B} 1$ = Lack of education

$\mathrm{C} 1=$ Not working

$\mathrm{C} 2=$ Working but odd income

D1 = Unable to work due to poor health

E1 = Spouse not working

E2 $=$ Spouse working but insufficient income

E3 = Adult children not working
$\mathrm{E} 4=$ Adult children working but income not sufficient

$\mathrm{F} 1=$ No family members help to provide financial expenses

$\mathrm{G} 1=$ Inability to pay monthly rent

$\mathrm{G} 2$ = Inability to pay back bank loan.

The SPI proposed in the present study consists of seven dimensions. Table 1 is the template which shows how the SPI could be computed by zakat institutions to determine whether a household is poor or not.

\begin{tabular}{|c|c|c|c|c|}
\hline $\begin{array}{l}\text { Dimensions } \\
\text { (a) }\end{array}$ & $\begin{array}{l}\text { Indicators } \\
\text { (b) }\end{array}$ & $\begin{array}{l}\text { Weightage } \\
\text { (c) }\end{array}$ & $\begin{array}{c}\text { Score } \\
\text { (0-not deprived, } \\
\text { 1-deprived) } \\
\text { (d) } \\
\end{array}$ & $\begin{array}{l}\text { Score } \\
\text { (c) } x(d)\end{array}$ \\
\hline \multirow[t]{3}{*}{$\begin{array}{l}\text { Ability } \\
\text { work }\end{array}$} & $\begin{array}{l}\text { Able to work but } \\
\text { inactive }\end{array}$ & 4.77 & & \\
\hline & $\begin{array}{l}\text { Able to work but not } \\
\text { able to get suitable } \\
\text { work }\end{array}$ & 4.77 & & \\
\hline & $\begin{array}{l}\text { Working but odd } \\
\text { income }\end{array}$ & 4.77 & & \\
\hline $\begin{array}{l}\text { Level of } \\
\text { education }\end{array}$ & $\begin{array}{l}\text { Lower level of } \\
\text { education }\end{array}$ & 14.3 & & \\
\hline \multirow[t]{2}{*}{$\begin{array}{l}\text { Status of } \\
\text { employment }\end{array}$} & $\begin{array}{l}\text { Not working and no } \\
\text { income }\end{array}$ & 7.15 & & \\
\hline & $\begin{array}{l}\text { Working but } \\
\text { insufficient income }\end{array}$ & 7.15 & & \\
\hline Health status & $\begin{array}{l}\text { Unable to work due } \\
\text { to poor health }\end{array}$ & 14.3 & & \\
\hline
\end{tabular}

Table 1. Computation of SPI 


\begin{tabular}{|c|c|c|}
\hline \multirow{4}{*}{$\begin{array}{l}\text { Other source } \\
\text { of income }\end{array}$} & Spouse not working & 3.58 \\
\hline & $\begin{array}{l}\text { Spouse working but } \\
\text { insufficient income }\end{array}$ & 3.58 \\
\hline & $\begin{array}{l}\text { Children (adult) not } \\
\text { working }\end{array}$ & 3.58 \\
\hline & $\begin{array}{l}\text { Children (adult) } \\
\text { working but income } \\
\text { insufficient }\end{array}$ & 3.58 \\
\hline $\begin{array}{l}\text { Moral } \\
\text { support }\end{array}$ & $\begin{array}{lr}\text { No family } & \text { members } \\
\text { support } & \text { financial } \\
\text { expenses } & \end{array}$ & 14.3 \\
\hline \multirow[t]{3}{*}{$\begin{array}{l}\text { Financial } \\
\text { stress }\end{array}$} & $\begin{array}{l}\text { Inability to pay } \\
\text { house rent }\end{array}$ & 7.15 \\
\hline & Inability to pay loan & 7.15 \\
\hline & & TWI \\
\hline
\end{tabular}

Columns (a) and (b) are the dimensions and their respective indicators, while column (c) presents the weightage of each dimension. If a household is deprived in any indicator, a score of 1 would be assigned and score 0 shows that a household is able to fulfil the needs of a particular indicator or variable. Then, the score of each indicator is computed in the score column by multiplying the weightage of a particular indicator with the score assigned, whether 1 or 0 . Finally, the scores of all indicators are finally totalled up to give the total score or TWI. This score, which is between 0 and 100 , gives the score for each household. Then, the TWI would be compared with the cut-off points to determine whether the household is poor, destitute or not poor. This table could be used by policy makers to determine whether each household is poor or not.

\section{ANALYSIS AND FINDINGS}

Adapted from Sulaiman, Azman and Khan (2014) in their study on Multidimensional Urban Poverty Index (MUPI), the score used in this study ranged from 0 to 100 . Thus, 0 means no deprivation at all on the selected indicators. While, 100 means subjective poverty deprivations based on the selected indicators. Intensity of multidimensional deprivation is negligible if household score is less than 20. Moderate multidimensional deprived if household score is b/w 20 and 50. High multidimensional deprived if household score is $>50$ but less than 75 . Very high multidimensional deprived if the household score is $>75$.

Table 2. Subjective Poverty Score

\begin{tabular}{llll}
\hline Score & Intensity & Subjective Poverty Deprivation & Status of Subjective Poor \\
\hline $\mathbf{0}$ & No deprivation & 7 & 112 \\
$\mathbf{2 0}$ & Low & 105 & Non-Poor \\
$\mathbf{2 0 - 5 0}$ & Moderate & 257 & \\
$\mathbf{5 0}$ & High & 118 & 396 \\
$\mathbf{> 7 5}$ & Very high & 21 & Poor \\
\hline
\end{tabular}

Table 2 illustrates status of subjective poor of respondents. A score of less than 20 is considered as non-poor.
Meanwhile score of 20 or more are considered as poor. 396 respondents $(78.1 \%)$ are considered as poor. 139 or 
$35.1 \%$ of the poor can be categorized as approach. very poor from subjective measurement

Figure 1. SPI Individual Score for Overall, and district of Central Melaka, Jasin and Alor Gajah

Overall individual score for State of Melaka

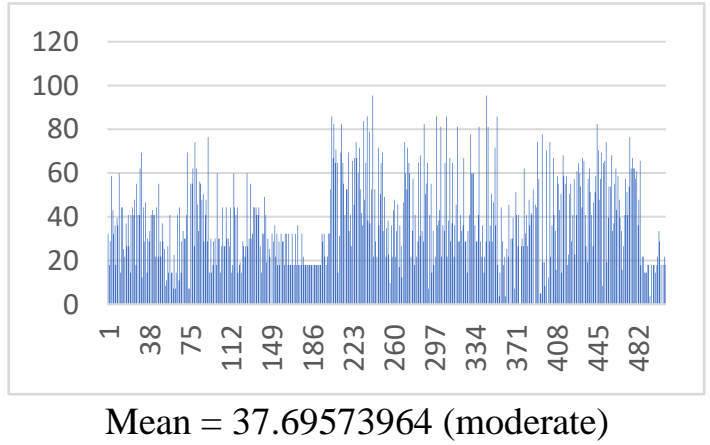

SPI Individual Score for district of Jasin.

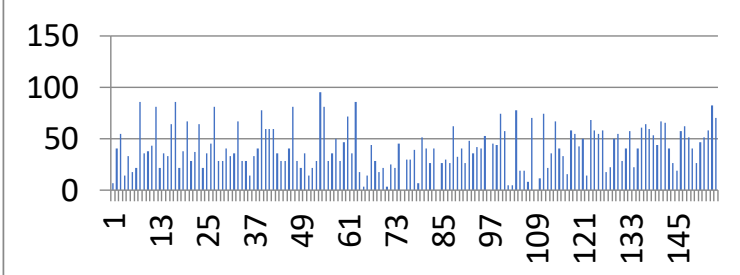

Mean $=40.30432($ moderate $)$

Findings from the study reported that Melaka as a whole experience moderate level of subjective poverty with a mean of 37.69 which is at the mid-level of moderate subjective poor (between 2050 score). Of the three districts, Jasin has the highest score of subjective poverty but it still considers as moderate level of subjective poor. This could be explained by the fact that Jasin is the least developed districts in the state of Melaka. While district of Central Melaka and Alor Gajah exhibited SPI individual score close to the state mean of SPI.

\section{CONCLUSION}

The current monetary approach is questioned to be incapable to reflect the multidimensional nature of poverty. As a result, policy makers and researchers in developed country decide on using other
SPI Individual Score for district of Central Melaka.

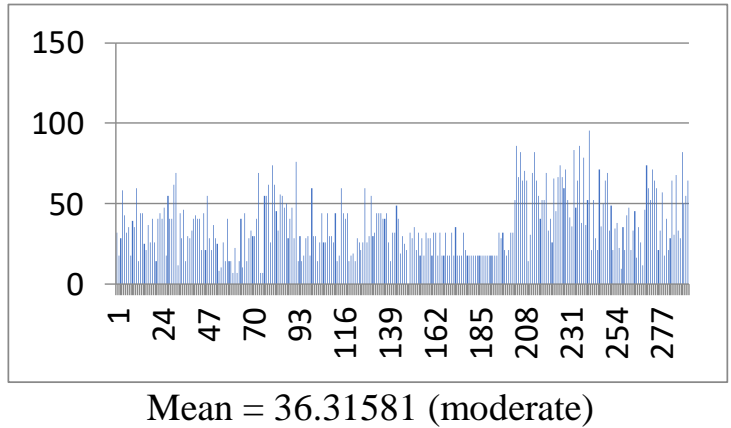

SPI Individual Score for district of Alor Gajah.

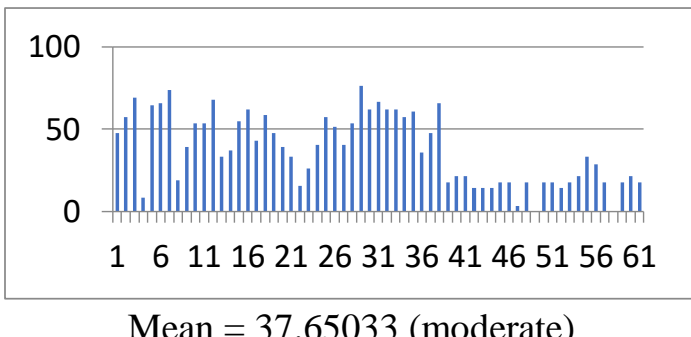

approaches such as capability and social exclusion approaches which are multidimensional in nature that includes non-monetary indicators. The need for subjective indicators must also be judged against the limitations of objective indicators. The choice of dimensions and indicators to be included in the measurement of proposed Subjective Poverty Index is guided both by common empirical practice as well as particular data considerations for Malaysia. Thus, by using the subjective poverty index, through this study, it was found that of the three districts, Jasin has the highest score of subjective poverty but it still considers as moderate level of subjective poor.

\section{ACKNOWLEDGEMENT}

The author would like to extend her acknowledgement for the support given by 
Higher Education Ministry of Malaysia under FRGS Grant for sponsoring her with a grant and State Islamic Religious Centre (SIRC) of Melaka for helping conducting the survey that make her capable of accomplishing the research paper.

\section{REFERENCES}

Alkire, S. (2010). Human development: Definitions, critiques, and related.

Alkire, S. (2007). The Missing Dimensions of Poverty Data: An Introduction. Oxford Development Studies, 35(4), 374-359.

Alkire, S. (2002). Dimensions of Human Development. World development, 30(2), 181-205.

Niemietz, K (2011). A New Understanding of Poverty. London: London Institute of Economic Affairs.

Laderchi, C. R., Saith, R., \& Steward, F. (2003). Does it matter that we don't agree on the definition of poverty? QEH Paper Series, 17, 141.

Laderchi, C. R. (2000). The Monetary Approach to Poverty: A Survey of Concept and Methods. QEH Paper Series, 58, 1-19.

OECD (2011). How's Life?: Measuring well-being, OECD Publishing, Paris, France.

Sen, A. K. (1977). Development as freedom $(D A F)$. Oxford. Oxford University Press.
Sen, A. K. (1992). Inequality reexamined. Cambridge, MA: Harvard University Press.

Sen, A. K. (1987). The standard of living: Lecture ii, lives and capabilities. In G. Hawthorn (Ed.), The standard of living (pp.20-38). Cambridge: The Tanner Lectures (Clare Hall).

Sulaiman, J., Azman,A \& Khan, Z. (2014). Re-modeling Urban Poverty: A Multidimensional Approach. International Journal of Social Work and Human Services Practice Horizon Research Publishing Vol.2. No.2 Apr, 2014, pp. 64-72.

World Bank (2003). World Development Report 2003/4: Making services work for poor people. New York: Oxford University Press.

Azhana Othman

Centre for Islamic Philanthropy and Social Finance (CIPSF)

Malaysia

azhana395@bdrmelaka.uitm.edu.my

Abd Halim Mohd Noor

Centre for Islamic Philanthropy and Social Finance (CIPSF)

Malaysia

Mohamed Saladin Abdul Rasool

Centre for Islamic Philanthropy and Social Finance (CIPSF)

Malaysia 